\title{
Jurist-Diction
}

Volume 4 No. 5 September 202

\section{Kekuatan Hukum Hasil Tes Urine Sebagai Alat Bukti Dalam Perkara Pidana Narkotika}

\author{
Rachmad Firmansyah \\ rakafirmansyahhhhh@gmail.com \\ Universitas Airlangga
}

\begin{abstract}
How to cite:
Rachmad Firmansyah,

'Kekuatan Hukum Hasil

Tes Urine Sebagai Alat Bukti Dalam Perkara Pidana

Narkotika' (2021) Vol. 4 No. 5

Jurist-Diction.

Histori artikel:

Submit 22 Juli 2021;

Diterima 15 Agustus 2021;

Diterbitkan 1 September 2021

DOI:

10.20473/jd.v4i5.29828

p-ISSN: $2721-8392$

e-ISSN: $2655-8297$
\end{abstract}

\section{Abstract}

In the context of carrying out the task of eradicating illicit abuse and illicit trafficking of Narcotics and Narcotics Precursors, the investigator has the authority to conduct urine tests on a person suspected of being an abuser, as stipulated in Article 75 letter 1 of Law Number 35 Year 2009 concerning Narcotics. The urine sample that has been taken will then be tested based on the development of science and technology in the narcotics testing laboratory which is then poured in the minutes of the test results. The minutes of the test results are valid evidence as determined by Article 184 of the Criminal Procedure Code. Someone who has a positive urine test result can be arrested and named as a suspect of narcotics abuse based on sufficient preliminary evidence. Suspects of abuse of Narcotics can be convicted in accordance with Article 127 paragraph (1) of the Narcotics Act. Thus the legal issues in this study is the Urine Test Results Are Used as the Basis for Assigning a Person to Be a Narcotics Abuse and Classification of Urine Test Results as Evidence As a Provision for Article 184 of the Criminal Procedure Code.

Keywords: Urine Test; Preliminary Evidence; Determination of Suspect; Valid Evidence.

Abstrak
Dalam rangka melaksanakan tugas pemberantasan penyalahgunaan dan
peredaran gelap Narkotika dan Prekursor Narkotika penyidik berwenang
melakukan tes urine terhadap seseorang yang diduga sebagai penyalah
guna, sebagaimana diatur pada Pasal 75 huruf 1 Undang-Undang Nomor
35 Tahun 2009 tentang Narkotika. Sampel urine yang telah diambil
selanjutnya akan diuji berdasarkan perkembangan ilmu pengetahuan dan
teknologi di laboratorium uji narkotika yang kemudian dituangkan dalam
berita acara hasil pengujian. Berita acara hasil pengujian merupakan alat
bukti yang sah sebagaimana ditentukan Pasal 184 KUHAP. Terhadap
seseorang yang hasil tes urinenya positif dapat ditangkap dan ditetapkan
sebagai tersangka penyalahgunaan Narkotika berdasarkan bukti
permulaan yang cukup. Tersangka penyalahgunaan Narkotika dapat
dipidana sebagaimana ketentuan Pasal 127 ayat (1) Undang-Undang
Narkotika. Dengan demikian rumusan masalah dalam penelitian ini
adalah Hasil Tes Urine Dijadikan Dasar Untuk Menetapkan Seseorang
Sebagai Tersangka Penyalahguna Narkotika dan Klasifikasi Hasil Tes
Urine Sebagai Alat Bukti Sebagaimana Ketentuan Pasal 184 KUHAP.
Kata Kunci: Tes Urine; Bukti Permulaan; Penetapan Tersangka; Alat
Bukti Yang Sah.
Copyright $\odot 2021$ Rachmad Firmansyah 


\section{Pendahuluan}

Tindak pidana narkotika merupakan salah satu tindak pidana yang sangat berbahaya karena dapat merusak generasi muda penerus bangsa secara fisik, karakter, sosial, serta keamanan dan ketertiban masyarakat bagi penyalahgunanya. Narkotika sendiri bukanlah zat yang asing lagi. "Narkotika merupakan salah satu obat yang diperlukan dalam dunia pengobatan, demikian juga dalam bidang penelitian untuk tujuan pendidikan, pengembangan ilmu dan penerapannya". Dalam tujuannya sebagai pengobatan, penelitian dan pengembangan ilmu, maka ketersediaannya perlu dijamin dengan pengawasan yang ketat supaya tidak terjadi penyalahgunaan narkotika dimana pada saat ini menjadi masalah besar pada setiap negara didunia. Indonesia salah satu negara yang pada era globalisasi saat ini menganggap bahwa sedang dalam darurat narkoba dan mengutamakan pemberantasan peredaran gelap narkotika sebagai prioritas utama dalam penegakan hukumnya. Hal ini dapat dilihat dari Undang-Undang RI Nomor 5 Tahun 1997 tentang Psikotropika (Lembaran Negara Republik Indonesia Nomor 3671, selanjutnya disebut sebagai UU Psikotropika) dan Undang-Undang RI Nomor 35 Tahun 2009 tentang Narkotika (Lembaran Negara Republik Indonesia Tahun 2009 Nomor 5062, selanjutnya disebut sebagai UU Narkotika) yang mengatur, mengawasi serta menindak peredaran dan penyalahgunaan narkotika.

UU Narkotika pada Pasal 1 ayat (1) dijelaskan bahwa narkotika adalah zat atau obat yang berasal dari tanaman atau bukan tanaman, baik sintetis maupun semisintetis, yang dapat menyebabkan penurunan atau perubahan kesadaran, hilangnya rasa, mengurangi sampai menghilangkan rasa nyeri, dan dapat menimbulkan ketergantungan, yang dibedakan ke dalam golongan-golongan sebagaimana terlampir dalam Undang-Undang ini. Zat atau obat tersebut apabila digunakan secara berkali-kali dapat membuat seseorang menjadi ketergantungan. "Ketergantungan ini bisa ringan dan bisa berat. Berat ringannya ketergantungan ini diukur dengan kenyataan sampai beberapa jauh ia bisa melepaskan diri dari

${ }^{1}$ Andi Hamzah, Perkembangan Hukum Pidana Khusus (Rineka Cipta 1991).[176]. 
penggunaan itu". ${ }^{2}$ Oleh karena itu penyalahgunaan narkotika sangat berbahaya dampaknya, sehingga harus dilakukan penanggulangan yang serius. "Penyalah Guna adalah orang yang menggunakan Narkotika tanpa hak atau melawan hukum". ${ }^{3}$ Upaya penanggulangan penyalahgunaan narkotika yang telah dilakukan yaitu upaya preventif(pencegahan) dengan mengedukasi seluruh elemen masyarakat dengan cara melakukan penyuluhan-penyuluhan mengenai dampak penyalahgunaan narkotika, yang dilakukan oleh Badan Narkotika Nasional (yang selanjutnya disingkat BNN) dan/atau kepolisian dan upaya represif (penindakan) yaitu menindak semua orang yang menyalahgunakan narkotika yang dilakukan kepolisian juga BNN yang bertindak sendiri-sendiri sesuai dengan undang-undang.

"Dalam rangka pencegahan dan pemberantasan penyalahgunaan dan peredaran gelap Narkotika dan Prekursor Narkotika, dengan Undang-Undang ini dibentuk Badan Narkotika Nasional, yang selanjutnya disingkat BNN". ${ }^{4}$ Dalam melaksanakan tugasnya BNN berwenang melakukan penyelidikan dan penyidikan penyalahgunaan dan peredaran gelap narkotika dan juga prekursor narkotika. Terhadap upaya penyelidikan dan penyidikan anggota BNN dalam menangkap seseorang yang diduga sebagai penyalahguna narkotika wajib mengumpulkan alat bukti yang cukup. Salah satu cara untuk membuktikan seseorang mengkonsumsi narkotika atau tidak yang juga merupakan kewenangan dari BNN, ialah, dengan melakukan tes urine. Didalam UU Narkotika pada Pasal 75 huruf 1 disebutkan bahwa "Dalam rangka melakukan penyidikan, penyidik BNN berwenang untuk melakukan tes urine, tes darah, tes rambut, tes asam dioksiribonukleat (DNA), dan/ atau tes bagian tubuh lainnya”.

Tes urine merupakan tindakan yang sering dilakukan oleh penyidik karena hasilnya bisa diketahui dalam kurun waktu yang cukup singkat dan efektif. Dalam kegiatan penyidikan, BNN dan Kepolisian sering melakukan razia pada sejumlah tempat hiburan dan tempat lainnya untuk menjaring penyalahguna narkotika. Pada

\footnotetext{
${ }^{2}$ Sudarto, Kapita Selekta Hukum Pidana (Alumni 1981).[39].

${ }^{3}$ Ps. 1 UU Narkotika No. 35/2009.

${ }^{4}$ ibid Pasal 64.
} 
penjelasan Pasal 75 huruf 1 UU Narkotika tersebut dilakukan untuk membuktikan ada tidaknya narkotika di dalam tubuh satu orang atau beberapa orang, dan tes asam dioksiribonukleat (DNA) untuk mengidentifikasi korban, pecandu dan tersangka.

Dalam hal seseorang yang diduga melakukan penyalahgunaan dan peredaran gelap narkotika penyidik BNN berwenang untuk menangkap dan menahan seseorang tersebut. Penangkapan dan penahanan yang dilakukan oleh penyidik BNN merupakan bentuk dari upaya paksa. Bentuk-bentuk upaya paksa antaralain penangkapan, penahanan, penggeledahan, penyitaan, pemeriksaan surat dan pemanggilan yang dalam hal ini diatur dalam Undang-Undang Nomor 8 Tahun 1981 tentang Hukum Acara Pidana (Lembaran Negara Republik Indonesia Tahun 1981 Nomor 76, Tambahan Lembaran Negara Republik Indonesia Nomor 3209, Kitab Undang-undang Hukum Acara Pidana yang selanjutnya disebut KUHAP).

Tersangka yang menyalahgunakan narkotika bagi diri sendiri dapat dipidana sesuai dengan ketentuan Pasal 127 ayat (1) yang menyebutkan:

(1) Setiap Penyalah Guna:

a. Narkotika Golongan I bagi diri sendiri dipidana dengan pidana penjara paling lama 4 (empat) tahun;

b. Narkotika Golongan II bagi diri sendiri dipidana dengan pidana penjara paling lama 2 (dua) tahun;

c. Narkotika Golongan III bagi diri sendiri dipidana dengan pidana penjara paling lama 1 (satu) tahun.

Konsep penyalah guna ialah bilamana pembuktian dari pada seorang yang diduga tersebut positif mengandung zat narkotika didalam tubuhnya. Dalam menjatuhkan hukuman terhadap sesorang yang diduga menyalahgunakan Narkotika hanya dapat diputuskan oleh hakim melalui proses hukum acara pidana yang diatur dalam KUHAP.

Mengenai penangkapan yang dilakukan terhadap penyalahguna narkotika dengan hanya hasil positif tes urine sebagai bukti permulaan masih menjadi permasalahan dimasyarakat. Seseorang yang hasil tes urinennya positif memilki dugaan kuat sebagai penyalahguna. Setelah didapati hasil tes urine yang positif penyidik akan membawa seseorang tersebut untuk dilakukan pemeriksaan yang 
kemudian dibuatkan berita acara (Berita Acara Pemeriksaan atau BAP). Namun demikian belum dapat dikatakan bahwa seseorang tersebut ditetapkan sebagai tersangka terlebih dijatuhi pidana.

\section{Dasar Penetapan Seseorang Sebagai Tersangka Penyalahguna Narkotika Melalui Tes Urine}

Penyidikan adalah serangkaian tindakan penyidik dalam hal dan menurut cara yang diatur dalam undang-undang acara pidana, untuk mencari serta mengumpulkan bukti yang dengan bukti itu membuat terang tentang tindak pidana yang terjadi dan guna menentukan tersangkanya seperti yang disebutkan pada ketentuan Pasal 1 angka 2 KUHAP. Menurut R. Soesilo pengertian penyidikan ditunjau dari sudut kata yaitu:

"Penyidikan berasal dari kata "sidik" yang berarti "terang". Jadi penyidikan mempunyai arti membuat terang atau jelas. "Sidik" juga berarti "bekas", sehingga menyidik berarti mencari bekas-bekas, dalam hal ini bekas-bekas kejahatan yang berarti setelah bekas-bekas ditemukan dan terkumpul, kejahatan menjadi terang. Penyidikan mempunyai arti tegas yaitu "mengusut", sehingga dari tindakan ini dapat diketahui peristiwa pidana yang telah terjadi dan siapakah orang yang telah melakukan perbuatan pidana tersebut". ${ }^{5}$

Dalam peyidikan, penyidik tindak pidana mencari dan mengumpulkan bukti, membuat terang tindak pidana yang terjadi, seta menemukan tersangkanya. Secara kogkrit, penyidikan adalah dalam rangka mendapatkan keterangan: ${ }^{6}$

a. Tindak pidana apa yang dilakukan;

b. Kapan tindak pidana itu dilakukan;

c. Dimana tindak pidana itu dilakukan;

d. Dengan apa tindak pidana itu dilakukan;

e. Bagaimana tindak pidana itu dilakukan;

f. Mengapa tindak pidana itu dilakukan;

g. Siapa pelakunya.

Dalam ruang lingkup hukum pidana, polisi dan pejabat pegawai negeri sipil merupakan penyidik sebagaimana yang diamanatkan oleh KUHAP yang merupakan sumber utama hukum acara pidana. Pada ketentuan Pasal 1 angka 1 KUHAP menyebutkan bahwa penyidik adalah pejabat polisi negara Republik

\footnotetext{
${ }^{5}$ R. Soesilo, Taktik dan Teknik Penyidikan Perkara Kriminal (Politea 1980).[17].

${ }^{6}$ Didik Endro Purwoleksono, Hukum Acara Pidana (AUP 2009).[6-7].
} 
Indonesia atau pejabat pegawai negeri sipil tertentu yang diberi wewenang khusus oleh undang-undang untuk melakukan penyidikan. Lebih lanjut dalam Pasal 6 ayat (1) menyebutkan penyidik terdiri atas pejabat polisi negara Republik Indonesia dan pejabat pegawai negeri sipil tertentu yag diberi wewenang khusus oleh undangundang. Kewenangan penyidik pejabat polisi negara Republik Indonesia diatur pada Pasal 7 ayat (1):

Penyidik sebagaimana dimaksud dalam Pasal 6 ayat (1) huruf a karena kewajibannya mempunyai wewenang:

a. menerima laporan atau pengaduan dari seorang tentang adanya tindak pidana;

b. melakukan tindakan pertama pada saat di tempat kejadian;

c. menyuruh berhenti seorang tersangka dan memeriksa tanda pengenal diri tersangka;

d. melakukan penangkapan, penahanan, penggeledahan dan penyitaan;

e. melakukan pemeriksaan dan penyitaan surat;

f. mengambil sidik jari dan memotret seorang;

g. memanggil orang untuk didengar dan diperiksa sebagai tersangka atau saksi;

h. mendatangkan orang ahli yang diperlukan dalam hubungannya dengan pemeriksaan perkara;

i. mengadakan penghentian penyidikan;

j. mengadakan tindakan lain menurut hukum yang bertanggung jawab.

Kewenangan penyidik pejabat pegawai negeri sipil diatur dalam Pasal 7 ayat (2). Pejabat pegawai negeri sipil mempunyai wewenang sesuai dengan undangundang yang menjadi dasar hukumnya masing-masing. ${ }^{7}$ Dalam menjalankan tugas penyidikan, penyidik pegawai negeri sipil wajib melakukan koordinasi dan berada di bawah pengawasan penyidik kepolisian.

Pada sistem peradilan pidana Indonesia KUHAP merupakan induk yang mengatur tentang tata cara dan aturan hukum acara pidana. Akan tetapi karena sistem Indonesia menganut sistem lex specialis derograt legi generali yaitu peraturan yang khusus mengalahkan peraturan yang umum, ${ }^{8}$ sehingga hukum acara pidana khusus dapat mengatur sendiri dan berbeda dari ketentuan KUHAP. Pengaturan mengenai

\footnotetext{
${ }^{7}$ Ps. 7 ayat (2) KUHAP.

${ }^{8}$ Ahmad Rifai, Penemuan Hukum oleh Hakim Dalam Perspektif Hukum Progresif (Sinar Grafika 2010.[90].
} 
narkotika diatur secara khusus dalam Undang-undang Nomor 35 Tahun 2009 tentang Narkotika yang selanjutnya disebut UU Narkotika. Dalam UU Narkotika penyidik dibedakan menjadi penyidik kepolisian negara Republik Indonesia, penyidik pegawai negeri sipil dan ditambah penyidik khusus yaitu penyidik Badan Narkotika Nasional (BNN) yang dibentuk oleh Presiden.

Dalam rangka mencegah dan memberantas peredaran gelap serta penyalahgunaan narkotika dibentuklah lembaga khusus yaitu badan narkotika nasional yang selanjutnya disingkat BNN. BNN merupakan lembaga pemerintah non kementrian yang berkedudukan dibawah presiden dan bertanggung jawab langsung kepada presiden dalam melakukan tugas dan wewenangnya. Dalam hal dibentuknya BNN diatur pada Pasal 64 UU Narkotika. Disebutkan bahwa BNN mempunyai kewenangan untuk melakukan penyidikan dalam tindak pidana narkotika. Oleh karenanya penyidik dalam tindak pidana narkotika juga berasal dari BNN. Penyidik BNN ${ }^{9}$ adalah penyidik yang berasal dari Penyidik Kepolisian Negara Republik Indonesia dan Penyidik Pegawai Negeri Sipil sesuai dengan peraturan perundang-undangan. Dalam ketentuan pada Pasal 71 UU Narkotika menentukan bahwa:

"Dalam melaksanakan tugas pemberantasan penyalahgunaan dan peredaran gelap Narkotika dan Prekursor Narkotika, BNN berwenang melakukan penyelidikan dan penyidikan penyalahgunaan dan peredaran gelap Narkotika dan Prekursor Narkotika".

Untuk melaksanakan kewenangan penyelidikan dan penyidikan terhadap penyalahgunaan dan peredaran gelap narkotika dan prekursor narkotika tersebut dilakukan sesuai dengan ketentuan Pasal 75 UU Narkotika :

Dalam rangka melakukan penyidikan, penyidik BNN berwenang:

a. melakukan penyelidikan atas kebenaran laporan serta keterangan tentang adanya penyalahgunaan dan peredaran gelap Narkotika dan Prekursor Narkotika;

b. memeriksa orang atau korporasi yang diduga melakukan penyalahgunaan dan peredaran gelap Narkotika dan Prekursor Narkotika;

c. memanggil orang untuk didengar keterangannya sebagai saksi;

d. menyuruh berhenti orang yang diduga melakukan penyalahgunaan dan

${ }^{9}$ Ps. 41 ayat (2) Peraturan Presiden tentang Badan Narkotika Nasional No.23/2010. 
peredaran gelap Narkotika dan Prekursor Narkotika serta memeriksa tanda pengenal diri tersangka;

e. memeriksa, menggeledah, dan menyita barang bukti tindak pidana dalam penyalahgunaan dan peredaran gelap Narkotika dan Prekursor Narkotika;

f. memeriksa surat dan/atau dokumen lain tentang penyalahgunaan dan peredaran gelap Narkotika dan Prekursor Narkotika;

g. menangkap dan menahan orang yang diduga melakukan penyalahgunaan dan peredaran gelap Narkotika dan Prekursor Narkotika;

h. melakukan interdiksi terhadap peredaran gelap Narkotika dan Prekursor Narkotika di seluruh wilayah juridiksi nasional;

i. melakukan penyadapan yang terkait dengan penyalahgunaan dan peredaran gelap Narkotika dan Prekursor Narkotika setelah terdapat bukti awal yang cukup;

j. melakukan teknik penyidikan pembelian terselubung dan penyerahan dibawah pengawasan;

k. memusnahkan Narkotika dan Prekursor Narkotika;

1. melakukan tes urine, tes darah, tes rambut, tes asam dioksiri bonukleat (DNA), dan/atau tes bagian tubuh lainnya;

m. mengambil sidik jari dan memotret tersangka;

n. melakukan pemindaian terhadap orang, barang, binatang, dan tanaman;

o. membuka dan memeriksa setiap barang kiriman melalui pos dan alat-alat perhubungan lainnya yang diduga mempunyai hubungan dengan penyalah gunaan dan peredaran gelap Narkotika dan Prekursor Narkotika;

p. melakukan penyegelan terhadap Narkotika dan Prekursor Narkotika yang disita;

q. melakukan uji laboratorium terhadap sampel dan barang bukti Narkotika dan Prekursor Narkotika;

r. meminta bantuan tenaga ahli yang diperlukan dalam hubungannya dengan tugas penyidikan penyalahgunaan dan peredaran gelap Narkotika dan Prekursor Narkotika;

s. menghentikan penyidikan apabila tidak cukup bukti adanya dugaan penyalahgunaan dan peredaran gelap Narkotika dan Prekursor Narkotika.

Wewenang BNN dalam melakukan tugas penyidikan juga diatur dalam Pasal 80. Ketentuan Pasal 75 dan Pasal 80 menunjukkan bahwa wewenang dari penyidik BNN sangat luas, sehingga dimungkinkan berbenturan dengan wewenang yang dimiliki oleh penyidik kepolisian dan penyidik pegawai negeri sipil. Dalam rangka melaksanakan tugas penyidikan, penyidik BNN memiliki kewenangan untuk melakukan penggeledahan dan melakukan tes urine, darah, tes rambut, tes asam dioksiribonukleat (DNA), dan/atau tes bagian tubuh lainnya sebagaimana tercantum dalam UU No. 35 Tahun 2009 Pasal 75. Artinya penyidik BNN merupakan penyidik khusus yang diberikan wewenang khusus dalam menjalankan tugas penyidikan. 
Penyidikan tindak pidana narkotika juga dapat dilakukan oleh penyidik kepolisian bersama-sama dengan BNN. Kendati polisi berwenang untuk melakukan penyidikan terhadap penyalahgunaan dan peredaran gelap Narkotika dan Prekursor Narkotika, penyidik kepolisian bukan merupakan penyidik tunggal. Wewenang polisi dalam melakukan penyidikan diatur dalam Pasal 81 UU Narkotika, yaitu: "Penyidik Kepolisian Negara Republik Indonesia dan penyidik BNN berwenang melakukan penyidikan terhadap penyalahgunaan dan peredaran gelap Narkotika dan Prekursor Narkotika berdasarkan Undang-Undang ini”.

Pengaturan melakukan penyidikan oleh penyidik kepolisian lebih lanjut diatur dalam Pasal 84, yaitu:

"Dalam melakukan penyidikan terhadap penyalahgunaan dan peredaran gelap Narkotika dan Prekursor Narkotika, penyidik Kepolisian Negara Republik Indonesia memberitahukan secara tertulis dimulainya penyidikan kepada penyidik BNN begitu pula sebaliknya".

Berkenaan dengan ketentuan tersebut, polisi dan BNN saling berkoordinasi guna mencegah terjadinya tumpang tindih kewenangan dalam penyidikan. Artinya wewenang polisi terikat dengan BNN dalam penyidikan kasus narkotika. Keterkaitan sebagaimana dimaksud dikarenakan penyidikan yang dilakukan oleh polisi harus diberitahukan secara tertulis kepada BNN. Sebaliknya juga, bilamana BNN yang melakukan penyidikan, maka penyidik BNN memberikan laporan kepada Kepolisian. Pengaturan ini pada hakikatnya dilakukan untuk menjaga sinergitas dalam menjalankan tugas dan wewenang yang sama yaitu memberantas penyalahgunaan dan peredaran gelap narkotika antara penyidik Kepolisian dan penyidik BNN.

Hal yang serupa juga didapati pada penyidik pegawai negeri sipil. Penyidik pegawai negeri sipil berwenang melakukan penyidikan terhadap tindak pidana penyalahgunaan Narkotika. Kewenangan penyidik pegawai negeri sipil pada UU Narkotika diatur sebagaimana ketentuan dalam Pasal 82, yaitu:

(1) Penyidik pegawai negeri sipil tertentu sebagaimana dimaksud dalam UndangUndang tentang Hukum Acara Pidana berwenang melakukan penyidikan terhadap tindak pidana penyalahgunaan Narkotika dan Prekursor Narkotika. 
(2) Penyidik pegawai negeri sipil tertentu sebagaimana dimaksud pada ayat (1) di lingkungan kementerian atau lembaga pemerintah nonkementerian yang lingkup tugas dan tanggung jawabnya di bidang Narkotika dan Prekursor Narkotika berwenang:

a. memeriksa kebenaran laporan serta keterangan tentang adanya dugaan penyalahgunaan Narkotika dan Prekursor Narkotika;

b. memeriksa orang yang diduga melakukan penyalahgunaan Narkotika dan Prekursor Narkotika;

c. meminta keterangan dan bahan bukti dari orang atau badan hukum sehubungan dengan penyalahgunaan Narkotika dan Prekursor Narkotika;

d. memeriksa bahan bukti atau barang bukti perkara penyalahgunaan Narkotika dan Prekursor Narkotika;

e. menyita bahan bukti atau barang bukti perkara penyalahgunaan Narkotika dan Prekursor Narkotika;

f. memeriksa surat dan/atau dokumen lain tentang adanya dugaan penyalahgunaan Narkotika dan Prekursor Narkotika;

g. meminta bantuan tenaga ahli untuk tugas penyidikan penyalahgunaan Narkotika dan Prekursor Narkotika; dan

h. menangkap orang yang diduga melakukan penyalahgunaan Narkotika dan Prekursor Narkotika.

Pembahasan tentang bukti permulaan yang cukup sangat penting karena berkaitan dengan penangkapan dan penetapan tersangka. Bukti permulaan yang cukup adalah proses untuk mencari unsur kesalahan terhadap peristiwa pidana. Dalam mencari kesalahan dan siapa yang bertanggung jawab pada peristiwa pidana merupakan substansi dari proses penyelidikan dan penyidikan. Upaya penyelidikan bukanlah fungsi yang berdiri sendiri melainkan hanya merupakan salah satu metode atau sub dari fungsi penyidikan. ${ }^{10}$

"Menurut P.A.F Lamintang, bukti permulaan yang cukup dalam rumusan Pasal 17 KUHAP itu harus diartikan sebagai bukti-bukti minimal, berupa alat-alat bukti seperti dimakud dalam Pasal 184 ayat (1) KUHAP, yang dapat menjamin bahwa penyidik tidak akan menjadi terpaksa untuk menghentikan penyidikannya terhadap seseorang yang disangka melakukan tindak pidana setelah terhadap orang tersebut dilakukan penangkapan". ${ }^{11}$

\footnotetext{
${ }^{10}$ Kepolisian Negara Republik Indonesia, Himpunan Bujuklak, Bujuklap, dan Bujukmin Proses Penyidikan Tindak Pidana (Kepolisian 2000).[17].

${ }^{11}$ P.A.F Lamintang, KUHAP dengan Pembahasan Secara Yuridis Menurut Yurisprudensi dan Ilmu Pengetahuan Hukum Pidana (Sinar Baru 1984).[117].
} 
Mengenai bukti permulaan yang cukup menurut penjelasan Pasal 17 KUHAP adalah bukti permulaan yang menduga adanya tindak pidana sesuai dengan bunyi Pasal 1 butir 14KUHAP. ${ }^{12}$ Pada ketentuan Pasal 1 butir 14 KUHAP tidak menerangkan secara spesifik apa yang dimaksud dengan bukti permulaan yang cukup. Dalam prakteknya, masalah mengenai penentuan bukti permulaan yang cukup bergantung dari penilaian penyelidik dan/atau penyidik. Menurut M. Yahya Harahap, yang paling rasional adalah apabila perkataan "permulaan" dibuang, sehingga kalimatnya berbunyi “didugakeras melakukan tindakpidanaberdasarkan buktiyang cukup". ${ }^{13} \mathrm{Jika}$ seperti itu rumusan Pasal 17 KUHAP, pengertian dan penerapannya lebih pasti. ${ }^{14}$ Apabila rumusan Pasal 17 KUHAP menyebutkan "bukti yang cukup" dan "bukti permulaan yang cukup" akan didapatkan pengertian yang serupa dengan pengertian yang terdapat pada Hukum Acara Pidana Amerika Serikat, yang menjelaskan bahwa untuk melakukan penahanan harus didasarkan pada affidavit ${ }^{15}$ dan testimony, ${ }^{16}$ yakni harus didasarkan pada adanya bukti dan kesaksian. ${ }^{17}$ Jika ditelaah lebih lanjut, bukti permulaan yang cukup menurut Hukum Acara Pidana Amerika Serikat, mempunyai kemiripan pengertian dengan rumusan Pasal 183 KUHAP, yakni harus berdasarkan pada prinsip "batas minimal pembuktian" yang terdiri dari sekurang-kurangnya dua alat bukti, bisa terdiri dari dua orang saksi atau saksi ditambah satu alat bukti lain. ${ }^{18}$ Bukti permulaan yang cukup seharusnya berkaitan erat dengan ketentuan Pasal 183 KUHAP yang mengatur tentang batas minimal alat bukti yaitu 2 (dua) alat bukti yang sah dan keyakinan hakim.

\footnotetext{
${ }^{12}$ Penjelasan Ps. 17 KUHAP

${ }^{13}$ M. Yahya Harahap, Pembahasan, Permasalahan dan Penerapan KUHAP, Penyidikan dan Penuntutan (Sinar Grafika 2000).[158].

${ }^{14}$ ibid.

${ }^{15}$ Definisi Affidavit adalah keterangan tertulis yang dimuat dibawah sumpah. Lihat J.C.T Simorangkir, et.al., Kamus Hukum (Sinar Grafika 2008).[5].

${ }^{16}$ Testimony berkaitan dengan Testimonial Evidence, Amerika Serikat yang menganut sistem common law, dalam Criminal Procedure Law mengunakan alat bukti: real evidance, documentary evidance, testimonial evidance dan judicial notice. Lihat Flora Dianti, "Apa Perbedaan Alat Bukti dengan Barang Bukti?", https://www.hukumonline.com/klinik/detail/ulasan/lt4e8ec99e4d2ae/ apa-perbedaan-alat-bukti-dengan-barang-bukti-/ (Hukum Online 2011) accessed on 10 November 2019.

${ }^{17}$ Harahap (n 13).

18 ibid.
} 
Pengaturan bukti permulaan yang cukup di dalam KUHAP dapat dikatakan masih kabur. KUHAP yang seharusnya menjadi pedoman dasar seluruh acara pidana kurang memberikan jalan keluar terkait definisi bukti permulaan yang cukup, karena hanya berkisar tentang manfaat dan dikaitkan dengan pencegahan kesewenangan aparat. Seharusnya secara jelas merinci tentang macam bukti apa saja, dari mana, dan siapa yang berwenang menguji kebenaran fakta dalam bukti permulaan yang cukup.

Pengertian mengenai bukti permulaan yang cukup yang masih kabur menjadi objek sengketa pada Mahkamah Konstitusi. Mahkamah Konstitusi pada tanggal 28 April 2015, sebagaimana dimaksud dalam Putusan nomor 21/PUU-XII/2014 manafsirkan lain terhadap frasa "bukti permulaan yang cukup". Kutipan putusan Mahkamah Konstitusi nomor 21/PUU-XII/2014 memuat beberapa pokok hal kaidah hukum baru, antara lain:

1. Frasa "bukti permulaan", "bukti permulaan yang cukup" dan "bukti yang cukup", sebagaimana dimaksud dalam pasal 1 angka 14, Pasal 17 dan Pasal 21 ayat (1) Undang-Undang nomor 8 Tahun 1981 tentang Kitab UndangUndang Hukum Acara Pidana (Lembaran Negara Republik Indonesia Tahun 1981, Nomor 76, Tambahan Lembaran Negara Republik Indonesia No.3209) bertentangan dengan Undang-Undang Dasar Negara Republik Indonesia Tahun 1945 sepanjang tidak dimaknai bahwa "bukti permulaan", "bukti permulaan yang cukup" dan "bukti yang cukup" adalah minimal dua alat bukti yang termuat dalam Pasal 184 Undang-Undang No.8 Tahun 1981 tentang Kitab Undang-Undang Hukum Acara Pidana.

2. Frasa "bukti permulaan", "bukti permulaan yang cukup" dan "bukti yang cukup", sebagaimana dimaksud dalam pasal 1 angka 14, Pasal 17 dan Pasal 21 ayat (1) Undang-Undang nomor 8 Tahun 1981 tentang Kitab Undang-Undang Hukum Acara Pidana (Lembaran Negara Republik Indonesia Tahun 1981, Nomor 76, Tambahan Lembaran Negara Republik Indonesia No.3209) tidak mempunyai kekuatan hukum mengikat sepanjang tidak dimaknai bahwa "bukti permulaan", "bukti permulaan yang cukup" dan "bukti yang cukup" adalah 
minimal dua alat bukti yang termuat dalam Pasal 184 Undang-Undang No.8

Tahun 1981 tentang Kitab Undang-Undang Hukum Acara Pidana. ${ }^{19}$

Dalam amar putusan nomor 21/PUU-XII/2014 Mahkamah Konstitusi menyatakan bahwa inkonstitusional bersyarat terhadap frasa "bukti yang cukup, "bukti permulaan yang cukup", dan "bukti yang cukup" dalam Pasal 1 butir 14, Pasal 17, dan Pasal 21 ayat (1) KUHAP. Mahkamah menilai frasa-frasa dalam KUHAP tersebut bertentangan dan tidak mempunyai kekuatan hukum mengikat sepanjang tidak dimaknai minimal dua alat bukti sesuai Pasal 184 KUHAP.

Sebagai pertimbangan Mahkamah Konstitusi dalam putusan tersebut karena KUHAP tidak memberi penjelasan mengenai batasan jumlah (alat bukti) dari frasa "bukti yang cukup, "bukti permulaan yang cukup", dan "bukti yang cukup". Mahkamah menganggap syarat minimum dua alat bukti dan pemeriksaan calon tersangka untuk transparansi dan perlindungan hak asasi seseorang agar sebelum seseorang ditetapkan sebagai tersangka telah dapat memberi keterangan secara seimbang. ${ }^{20}$ Tujuan daripada itu adalah untuk menghindari adanya tindakan sewenang-wenang oleh penyidik dalam menentukan bukti permulaan yang cukup.

Pengaturan mengenai narkotika diatur dalam Undang-Undang Nomor 35 Tahun 2009 tentang Narkotika. Pada Undang-Undang Nomor 35 Tahun 2009 tentang Narkotika tersebut, orang yang menggunakan narkotika dikualifikasikan menjadi dua, yaitu penyalah guna dan pecandu narkotika. Penyalah guna adalah orang yang menggunakan Narkotika tanpa hak atau melawan hukum. ${ }^{21}$ Pecandu Narkotika adalah orang yang menggunakan atau menyalahgunakan Narkotika dan dalam keadaan ketergantungan pada narkotika, baik secara fisik maupun psikis. ${ }^{22}$ Baik terhadap penyalah guna maupun pecandu di dalam tubuhnya akan didapati

19 Boris Tampubolon, 'Penjelasan "Bukti yang Cukup” Di Dalam KUHAP', https:// konsultanhukum.web.id/ini-penjelasan-bukti-yang-cukup-di-dalam-kuhap/, (Konsultan Hukum 2011) accessed on 9 November 2019.

${ }^{20}$ Tri Jata Ayu Pramesthi, 'Arti “Bukti Permulaan Yang Cukup” Dalam Hukum Acara Pidana', https://www.hukumonline.com/klinik/detail/ulasan/lt5940eb061 eb61/arti-bukti-permulaan-yangcukup-dalam-hukum-acara-pidana/ (Hukum Online 2017) accessed on 9 November 2019.

${ }^{21}$ Ps. 1 angka 15 UU Narkotika.

22 ibid Ps. 1 angka 13. 
kandungan zat-zat sejenis Narkotika dan Prekursor Narkotika.

Untuk membuktikan adanya kandungan zat Narkotika dalam tubuh seseorang dapat dilakukan sesuai dengan perkembangan teknologi dan ilmu pengetahuan. Salah satu metode untuk membuktikannya ialah dengan melakukan tes urine. Dalam penjelasan Pasal 75 huruf 1 Undang-Undang Nomor 35 Tahun 2009 tentang Narkotika, dijelaskan bahwa tes urine, tes darah, tes rambut, dan tes bagian tubuh lainnya dilakukan sesuai dengan perkembangan ilmu pengetahuan dan teknologi untuk membuktikan ada tidaknya narkotika di dalam tubuh seseorang.

Tes untuk mengecek kadar narkotika dalam tubuh dinamakan dengan tes toksikologi atau skrining toksikologi. Tes toksikologi dilakukan untuk mengecek adanya kandungan obat-obatan atau bahan kimia seperti narkotika dalam urine, darah, dan air liur. ${ }^{23}$ Urine merupakan salah satu spesimen biologi yang bisa diuji di laboratorium. Spesimen biologi adalah cairan, potongan atau bagian lainnya dari tubuh manusia, dapat berupa darah, plasma, serum, urine atau lainnya. ${ }^{24}$ Menurut dokter Firdaus Fabrice Hannanu, umumnya zat Narkotika dapat terdeteksi pada urine sekitar 2-3 hari setelah pemakaian terakhir, namun pada pemakaian dosis tinggi dan kronik (jangka panjang) dapat membutuhkan waktu sekitar 10 hari hingga dapat dikeluarkan sepenuhnya dari serum atau cairan tubuh. ${ }^{25}$ Kandungan zat Narkotika yang ada dalam sampel urine selama 3 hari setelah pemakaian terakhir menunjukkan bahwa tes urine merupakan metode yang efektif dan efisien untuk mengetahui indikasi penyalah guna.

Untuk mendapatkan hasil yang definit dalam pengujian sampel urine, maka harus ditentukan jumlahnya. Persyaratan teknis untuk sampel uji atau barang bukti berbentuk spesimen biologi:

${ }^{23}$ Fauzan Budi P, 'Berapa Lama Biasanya Narkotika Bertahan dalam Darah dan Urin?', https://hellosehat.com/hidup-sehat/fakta-unik/narkoba-dalam-urin-darah/ (Hello Sehat 2017) accessed on 14 November 2019.

${ }^{24}$ Ps. 1 angka 8 Perka BNN tentang Pedoman Teknis Penyelenggaraan Pelayanan Laboratorium Pengujian Narkoba Pada Badan Narkotika Nasional No. 5/2010.

${ }^{25}$ Firdaus Febrice Hannanu, "Berapa lama kandungan narkoba hilang dalam urine dan darah?”, https://www.alodokter.com/komunitas/topic/berapa-lama-hilang-zat-kandungan-narkobadalam-urien-dan-darah (Alo Dokter 2019) accessed on 14 November 2019. 
a. kondisi sampel atau barang bukti sesuai dengan rincian yang tercantum dalam surat permohonan dan berkas lampirannya;

b. jumlah sampel yang dikirimkan diatur sebagai berikut:

- urine paling sedikit 50 (lima puluh) mililiter (ml) dalam satu botol;

- darah paling sedikit 10 (sepuluh) mililiter ( $\mathrm{ml}$ ) atau;

- plasma/serum paling sedikit 5 (lima) mililiter (ml); untuk setiap jenis pengujian;

c. wadah sampel terbuat dari bahan yang tidak mudah pecah, bebas kontaminan, dan tidak bereaksi kimia terhadap sampel, tertutup dengan baik, tersegel, tidak bocor dan diberi identitas atau dilabel;

d. sampel spesimen biologi harus dipastikan tidak terdapat zat atau barang/materiil yang ditambahkan yang akan mempengaruhi hasil pengujian. ${ }^{26}$

Sampel urine yang layak untuk diuji minimal berjumlah 50 mililiter. Pengujian spesimen biologi yang diduga mengandung narkotika dilakukan untuk keperluan pembuktian perkara (pro justitia), rehabilitasi, ilmu pengetahuan dan teknologi serta pendidikan dan pelatihan sebagaimana diatur pada Pasal 2 ayat (1) Peraturan Kepala Badan Narkotika Nasional Nomor 5 Tahun 2010 tentang Pedoman Teknis Penyelenggaraan Pelayanan Laboratorium Pengujian Narkoba Pada Badan Narkotika Nasional.

Penyidik tindak pidana narkotika diberikan kewenangan untuk melakukan tes urine, tes darah, tes rambut, tes asam dioksiribonukleat (DNA) dan/atau tes bagian tubuh lainnya. Kewenangan penyidik sebagaimana dimaksud bertujuan untuk mengumpulkan bukti guna kepentingan penyidikan perkara Narkotika. Pada saat penyidik melakukan tes urine, urine tersebut kemudian dimasukkan ke dalam wadah atau botol plastik. Wadah atau botol plastik yang telah dipakai untuk pengisian urine tersebut lalu disegel dan diberi pita merah untuk selanjutnya dikirim ke laboratorium forensik. Setelah itu dibuatkan berita acara pengambilan urine terhadap seseorang tersebut. Pada berita acara pengambilan urine tersebut dilampirkan tanggal dan waktu pada saat pengambilan urine. Dalam berita acara tersebut tertera nama penyidik yang mengambil sampel urine dan disebutkan pula di dalamnya nama, tempat dan tanggal lahir, suku/ bangsa, agama, pekerjaan serta alamat terhadap seseorang yang dijadikan calon

\footnotetext{
${ }^{26}$ Ps. 5 ayat (2) Perka BNN No. 5/2010.
} 
tersangka. Kemudian dijelaskan pula secara detail mulai dari awal hingga akhir proses pengambilan urine tersangka dilakukan. Berita acara pengambilan urine ini dibuat dengan sebenar-benarnya atas sumpah jabatan penyidik dan ditanda tangani oleh penyidik dan seseorang tersebut.

Setelah penyidik melakukan tes urine terhadap seseorang tersebut dan hasilnya positif, maka untuk mengetahui kebenaran hasil tes urine, sampel urine tersebut akan diperiksa lagi oleh laboratorium forensik apakah sebelumnya memang positif menggunakan narkotika guna diketahui jenis zat yang terkandung di dalamnya. Sampel urine yang diperoleh penyidik tersebut kemudian diperiksa di Unit Pelaksana Teknis Laboratorium Uji Narkoba BNN yang diatur dengan Perkap BNN Nomor 5 Tahun 2010. Dalam tahapan pemeriksaan pada laboratorium forensik hasil dari pengujian sampel urine akan dituangkan dalam bentuk berita acara pengujian untuk keperluan pembuktian perkara sebagaimana ketentuan Pasal 6 ayat (2) huruf a Perkap BNN Nomor 5 Tahun 2010. Demikian sampel tes urine yang diuji hasilnya akan dituliskan dalam bentuk surat berupa berita acara hasil pengujian.

Dalam hal berita acara hasil tes urine seseorang yang terbukti positif mengandung zat narkotika, maka dapat diduga kuat orang tersebut merupakan penyalah guna narkotika. Demikian juga apabila hasil pengujian sample urine tersebut negatif, maka tidak dapat dikatan orang tersebut sebagai penyalahguna. Terhadap orang yang dinyatakan sebagai penyalah guna berarti melanggar ketentuan Pasal 127 ayat (1) Undang-Undang No. 35 Tahun 2009 tentang Narkotika, yang menyebutkan bahwa:

1) Setiap Penyalah Guna:

a. Narkotika Golongan I bagi diri sendiri dipidana dengan pidana penjara paling lama 4 (empat) tahun;

b. Narkotika Golongan II bagi diri sendiri dipidana dengan pidana penjara paling lama 2 (dua) tahun;

c. Narkotika Golongan III bagi diri sendiri dipidana dengan pidana penjara paling lama 1 (satu) tahun.

Undang-Undang No. 35 Tahun 2009 tentang Narkotika menganut doktrin strict liability atau pertanggung jawaban mutlak, meskipun tidak disebutkan secara jelas dan gamblang. Pertanggung jawaban mutlak yang dimaksud adalah pertanggung 
jawaban atas perbuatan yang dilakukan tanpa harus dibuktikan unsur kesalahannya. Menurut Astutik yang dituliskan pada media hukumonline mengatakan bahwa:

"dalam UU Narkotika hanya dirumuskan unsur tanpa hak atau melawan hukum, yang artinya jika pelaku menyalahgunakan atau memproduksi atau mengedarkan atau membawa atau memiliki, dan atau sebagainya yang tidak sesuai dengan prosedur yang telah ditetapkan UU Narkotika maka pelaku sudah dianggap sengaja melanggar pasal-pasal dalam UU Narkotika". ${ }^{27}$

Sehingga seseorang dapat dipidana selama perbuatan yang dilakukan telah memenuhi unsur-unsur dalam rumusan suatu pasal dalam Undang-undang tersebut tanpa harus memenuhi unsur kesalahannya.

Jika melihat Pasal 127 ayat (1) UU Narkotika, maka terdapat unsur setiap penyalah guna. Penyalah guna sebagaimana dimaksudkan adalah orang yang menggunakan Narkotika tanpa hak dan melawan hukum. Untuk mengetahui seseorang sebagai penyalah guna salah satunya dengan dilakukan tes urine, karena dengan tes urine dapat membuktikan kandungan zat Narkotika dalam tubuh seseorang.

Kedudukan hasil tes urine sangat berpengaruh pada pemeriksaan tindak pidana Narkotika. Seseorang yang hasil tes urinennya positif dapat diduga kuat sebagai penyalahguna Narkotika. Terhadap hasil tes urine positif yang dituangkan dalam bentuk berita acara pengujian merupakan alat bukti yang sah. Dalam tahap penyidikan, penangkapan dan penetapan tersangka dapat dilakukan berdasarkan bukti permulaan yang cukup. Bukti permulaan yang cukup untuk menetapkan seseorang menjadi tersangka, yaitu didasarkan pada Laporan Polisi dan ditambah 1 (satu) alat bukti yang sah (sebagaimana ditentukan Pasal 184 KUHAP). Ihwalnya hasil positif tes urine mempunyai kekuatan hukum sebagai bukti permulaan yang cukup dengan ditambah laporan polisi. Sehingga, seseorang yang hasil tes urinenya positif dapat ditangkap dan ditetapkan sebagai tersangka tindak pidana penyalahgunaan Narkotika.

\footnotetext{
${ }^{27}$ Dimas Hutomo, 'Strict Liability Dalam Pidana Narkotika', https://www.hukumonline. com/klinik/detail/lt5a54974660b45/strict-liability-dalam-pidana-narkotika/ (Klinik Hukum Online 2018) accessed on 13 November 2019.
} 


\section{Klasifikasi Hasil Tes Urine Sebagai Alat Bukti Dalam Ketentuan Pasal 184 KUHAP}

Hukum Acara Pidana termuat dalam Undang-Undang Nomor 8 Tahun 1981 tentang Hukum Acara Pidana yang secara umum disebut dengan Kitab UndangUndang Hukum Acara Pidana (KUHAP). KUHAP merupakan suatu rangkaian peraturan tentang bagaimana cara para aparatur penegak hukum seperti Polisi, Jaksa, Hakim dan Penasihat Hukum bertindak dalam menegakkan hukum. Oleh karena itu, tujuan dari diselenggarakannya hukum acara pidana ialah:

1. Mencari kebenaran materiil;

2. Mengambil putusan yang didasarkan atas hukum keyakinan dan rasa keadilan;

3. Pelaksanaan putusan terhadap seseorang yang harus dinyatakan bersalah. ${ }^{28}$

Salah satu tujuan dari hukum acara pidana ialah mencari kebenaran materiil, yaitu mencari kebenaran sejati atau yang sesungguhnya. Hukum pidana dalam mencari kebenaran materiil maka peristiwanya harus terbukti (beyond reasonable doubt). ${ }^{29}$ Untuk mencari kebenaran materiil haruslah dilakukan suatu pembuktian, sebab pembuktian merupakan unsur penting dalam hukum acara pidana. Secara harfiah, menurut KBBI, pembuktian adalah suatu proses perbuatan, cara membuktikan, suatu usaha menentukan benar atau salahnya si terdakwa di dalam sidang pengadilan. ${ }^{30}$ Dalam hal diperlukannya pembuktian pada suatu peristiwa dibutuhkan bukti-bukti yang di dalam hukum acara pidana disebut dengan alat bukti.

Keberadaan alat bukti sangat penting baik pada tahap penyidikan maupun pada tahap pemidanaan di pengadilan. Pada tahap penyidikan, seseorang yang diduga melakukan tindak pidana dapat ditangkap dan ditetapkan menjadi tersangka berdasarkan sekurang-kurangnya satu Laporan Polisi ditambah dengan alat bukti yang sah. Demikian juga untuk menentukan putusan hukum yang diambil oleh hakim yang berwenang memeriksa dan mengadili dalam sistem peradilan. Hakim

\footnotetext{
${ }^{28}$ Tri Andrisman, Hukum Acara Pidana (Bagian Hukum Pidana Fakultas Hukum Universitas Lampung 2010.[14].

${ }^{29}$ Andi Sofyan, Hukum Acara Pidana Suatu Pengantar (Rangkang Education 2013.[241].

${ }^{30}$ Ebta Setiawan, “arti atau makna pembuktian” https://kbbi.web.id/bukti (KBBI 2019) accessed on 1 Desember 2019.
} 
tidak boleh menjatuhkan pidana kepada seseorang kecuali apabila dengan sekurangkurangnya dua alat bukti yang sah ia memperoleh keyakinan bahwa suatu tindak pidana benar-benar terjadi dan bahwa terdakwalah yang bersalah melakukannya. ${ }^{31}$ Dapat dikatakan bahwa kekuatan alat bukti dapat membuktikan putusan pengadilan yang dianggap benar sehingga si tersangka dinyatakan bersalah. Apabila hakim dalam menilai dan mempertimbangkan alat bukti ia memperoleh keyakinan, maka ia dapat memutuskan salah atau tidaknya terdakwa. Dari sistem pembuktian ini, salah atau tidaknya seorang terdakwa ditentukan keyakinan hakim yang didasarkan kepada cara dan dengan alat-alat bukti yang sah menurut undang-undang. ${ }^{32}$

Sumber hukum atau dasar hukum pengaturan tentang alat bukti yang sah terdapat pada Pasal 184 ayat (1) KUHAP:

(1) Alat bukti yang sah ialah:
a. Keterangan saksi;
b. Keterangan ahli;
c. Surat;
d. Petunjuk; dan
e. Keterangan terdakwa.

Lima jenis alat bukti tersebut memiliki kekuatan pembuktian yang sama dalam sistem hukum acara pidana. Urutan sebagaimana yang diatur didalam Pasal tersebut merupakan urutan sebagaimana pada pemeriksaan persidangan. Pengaturan alat bukti secara terbatas menyebabkan tidak dimungkinkan penggunaan alat bukti lain dalam penjatuhan pidana, karena hakim memiliki keterikatan dengan penggunaan alat bukti yang diatur dalam pasal 184 tersebut.

\section{a. Keterangan Saksi}

Keterangan saksi sebagai alat bukti ialah apa yang saksi nyatakan di sidang pengadilan (Pasal 185 ayat (1) KUHAP). Jika dihubungkan dengan ketentuan Pasal 1 butir 27 KUHAP maka yang harus diterangkan dalam sidang adalah:

1) apa yang saksi dengar sendiri;

2) apa yang saksi lihat sendiri;

\footnotetext{
${ }^{31}$ Ps. 183 KUHAP

${ }^{32}$ Tolib Effendi, Dasar Dasar Hukum Acara Pidana (Perkembangan dan Pembaharuan di Indonesia) (Setara Press 2014.[171].
} 
3) apa yang saksi alami sendiri.

Selain keterangan saksi di depan persidangan sesuai pengaturan yang Pasal 185 ayat (1) KUHAP, ditentukan juga keterangan saksi di bawah sumpah yang dibacakan di persidangan, yaitu sesuai ketentuan Pasal 162 KUHAP.

Pasal 162 KUHAP:

(1) Jika saksi sesudah memberi keterangan dalam penyidikan meninggal dunia atau karena halangan yang sah tidak dapat hadir di sidang atau karena sebab lain yang berhubungan dengan kepentingan Negara, maka keterangan yang telah diberikannya itu dibacakan.

(2) Jika keterangan itu sebelumnya telah diberikan di bawah sumpah, maka keterangan itu disamakan nilainya dengan keterangan saksi di bawah sumpah yang diucapkan di sidang.

\section{b. Keterangan Ahli}

Keterangan ahli diatur dalam Pasal 186 KUHAP. Keterangan ahli ialah apa yang seorang ahli nyatakan di sidang pengadilan. ${ }^{33}$ Dalam hal keterangan ahli dibutuhkan untuk kepentingan pemeriksaan guna membuat terang suatu perkara pidana sebagaimana disebutkan Pasal 1 butir 28 KUHAP. Keterangan ahli sebagai alat bukti baru diperlukan ketika dalam suatu proses pemeriksaan di tingkat penyidikan sesuai dengan ketentuan Pasal 120 KUHAP, maupun di pengadilan dihadapkan pada suatu permasalahan yang perlu diberikan penjelasan khusus, yang sebelumnya tidak dapat dimengerti atau dipahami oleh orang awam. Oleh karena itu, terhadap ahli yang dihadirkan wajib untuk memberikan keterangan yang objektif dan dapat dipertanggungjawabkan sebagai suatu penyeimbang.

Pada pemeriksaan tingkat pengadilan majelis hakim sudah sepatutnya dapat memilah, menilai dan menguji pendapat seorang ahli, termasuk adanya potensi konflik kepentingan, sehingga objektifitas dari keterangan ahli dapat dipertanggungjawabkan. Keahlian seorang ahli diukur dari tingkat pendidikannya atau pengalamannya dibidang-bidang tertentu. Misalnya jika perkara tindak pidana Narkotika, maka ahli yang patut diajukan ialah seorang dokter atau pakar dalam hal obat-obatan dan zat-zat kimia, sehingga dari segi teknis tentang

${ }^{33}$ Ps. 186 KUHAP. 
penyalahgunaan zat Narkotika ia dapat memberikan keterangan untuk membuat jelas dan terang perkara tersebut.

Konsep alat bukti keterangan ahli, dengan pembedaan pengambilan waktu keterangannya akan dinilai sebagai dua alat bukti, yaitu sebagai alat bukti surat untuk keterangan ahli yang diberikan di luar sidang dalam bentuk laporan (Pasal 187 huruf c dan Pasal 133) KUHAP dan sebagai alat bukti keterangan ahli, pada keterangan yang diberikan dalam sidang. Perkembangan alat bukti ini terutama dipengaruhi oleh perkembangan ilmu pengetahuan dan teknologi serta perkembangan kejahatan dan modus operandinya.

Akhir-akhir ini pada penegakkan hukum di Indonesia semakin dikenal konsep pembuktian dengan menggunakan Deoxyribo Nucleic Acid Fingerprinting atau sering disebut DNA. Penerimaan konsep ini yang tidak diatur secara tegas dalam KUHAP membuat penegak hukum harus menggali lebih dalam untuk menyelaraskan pengaturan alat bukti pada KUHAP dengan konsep ini. Dari lima alat bukti yang diatur pada KUHAP, konsep DNA ini sebenarnya dapat masuk dalam perkembangan tiga kategori alat bukti, yaitu keterangan ahli, surat dan petunjuk.

1) Alat bukti keterangan ahli; yaitu apabila seorang ahli memberikan keterangan di depan sidang pengadilan mengenai analisisnya tentang informasi genetik yang tercantum di dalam hasil tes DNA dan memberikan penjelasan ilmiah tentang cara dan proses pengukuran DNA tersebut;

2) Alat bukti surat; yaitu bila bukti tes DNA tersebut dituangkan dalam bentuk visum et repertum atau surat laporan medis dari seorang ahli atas permintaan resmi dari penyidik maupun oleh penuntut umum;

3) Alat bukti petunjuk; yaitu apabila dalam mengajukan tes DNA di persidangan dapat dihubungkan dengan kejadian atau keadaan (fakta) yang ada, yang menandakan telah terjadi suatu tindak pidana dan siapa pelakunya.

\section{c. Surat}

Alat bukti surat diatur pada Pasal 187 KUHAP. Surat sebagaimana dijelaskan dalam KUHAP berbeda dengan pengaturan surat yang diatur dalam hukum perdata 
formil. Dalam hukum acara perdata dibagi secara tegas mengenai alat bukti surat, yaitu akta otentik dan akta di bawah tangan.

Akta otentik adalah suatu akta yang dibuat dalam bentuk yang ditentukan Undang-Undang oleh atau dihadapan pejabat umum yang berwenang untuk itu dan tempat akta itu dibuat. ${ }^{34} \mathrm{Hal}$ tersebut berarti bahwa pembuatan akta otentik harus memiliki dasar hukum, yaitu peraturan perundang-undangan yang memerintahkan agar suatu keadaan atau perbuatan baru dapat dibuktikan dengan adanya akta otentik. Sebagai contoh akta otentik ialah akta nikah, tanpa adanya akta nikah maka perkawinan tidak dapat dibuktikan, juga dalam pembuatannya dilakukan oleh pejabat Kantor Urusan Agama (KUA). Dalam hal pembuktian, akta otentik mempunyai kekuatan pembuktian yang sempurna, yakni bukti yang harus dianggap benar kecuali pihak lain dapat menyangkal kebenarannya.

Akta dibawah tangan adalah surat atau tulisan yang dibuat oleh para pihak tanpa adanya campur tangan pejabat umum dan peraturan perundang-undangan tidakmengharuskannya. Dapat dikatakan bahwa akta dibawah tangan bertolak dengan akta otentik secara koseptual. Sebagai contoh ialah surat perjanjian sewa menyewa yang dibuat dan disetujui oleh pihak penyewa dan pihak yang menyewakan. Meskipun akta dibawah tangan dapat dapat dijadikan sebagai alat bukti, namun kekuatan pembuktiannya tidak sempurna sebagaimana akta otentik. Kekuatan pembuktian akta dibawah tangan meliputi kebenaran identitas penanda tangan dan kebenaran identitas orang yang memberikan keterangan.

KUHAP tidak menjelaskan kekuatan pembuktian akta otentik dengan akta di bawah tangan. Alat bukti surat diklasifikasikan menjadi 4 jenis, antara lain:

a. Berita acara dan surat lain dalam bentuk resmi yang dibuat oleh pejabat umum yang berwenang atau yang dibuat dihadapannya, yang memuat keterangan tentang kejadian atau keadaan yang didengar, dilihat atau yang dialaminya sendiri disertai dengan alasan yang jelas dan tegas tentang keterangan itu;

b. Surat yang dibuat menurut ketentuan peraturan perundang-undangan atau surat yang dibuat oleh pejabat mengenai hal yang termasuk dalam tata laksana yang menjadi tanggung jawabnya dan yang diperuntukkan bagi pembuktian suatu

${ }^{34}$ Ps. 1868 KUHPerdata. 
hal atau suatu keadaan;

c. Suratketerangan dari seorang ahli yang memuat pendapat berdasarkankeahliannya mengenai suatu hal atau keadaan yang diminta secara resmi dari padanya;

d. Surat lain yang hanya dapat berlaku jika ada hubungannya isi dari alat pembuktian yang lain. ${ }^{35}$

Sebagai contoh hasil tes urine sebagai alat bukti dalam suatu tindak pidana penyalahgunaan Narkotika. Tes urine dilakukan untuk menilai ada atau tidaknya kandungan zat Narkotika pada tubuh seorang penyalah guna. Praktiknya, setelah sampel urine diambil untuk dilakukan pengujian di laboratorium, hasil pengujian dari laboratorium tersebut dituliskan pada berita acara pengujian. Berita acara tersebut merupakan alat bukti surat.

Pengaturan alat bukti surat pada Pasal 187 KUHAP tidak mengatur mengenai surat dalam bentuk elektronik ataupun bentuk lain selain surat dalam bentuk kertas, sehingga surat dalam bentuk elektronik belum dapat tempat pada persidangan pidana sebagai alat bukti. Perkembangan dalam sidang pengadilan di Indonesia yang sudah terpengaruh seiring perkembangan zaman dan teknologi memaksa pentingnya pengaturan penerimaan surat dalam bentuk elektronik sebagai alat bukti, namun limitasi dalam Pasal 187 KUHAP tersebut membatasi untuk penggunaannya.

\section{d. Petunjuk}

Pasal 188 (1) KUHAP mengatakan bahwa petunjuk adalah perbuatan, kejadian atau keadaan yang karena persesuaiannya, baik antara yang satu dengan yang lain maupun dengan tindak pidana itu sendiri menandakan bahwa telah terjadi suatu tindak pidana dan siapa pelakunya. Dari kata adanya persesuaian dapat disimpulkan bahwa sekurang-kurangnya harus ada dua petunjuk untuk mendapatkan bukti yang sah. Dalam hal bukti petunjuk, kekuatan pembuktiannya terletak pada hubungan banyak atau tidaknya perbuatan yang dianggap sebagai petunjuk dengan perbuatan yang didakwakan kepada terdakwa. ${ }^{36}$

Kemudian dalam ayat selanjutnya disebutkan bahwa petunjuk hanya dapat diperoleh dari keterangan saksi, surat dan keterangan terdakwa. Demikian

\footnotetext{
${ }^{35}$ Ps. 187 KUHAP.

${ }^{36}$ Eddy O.S Hiariej, Teori \& Hukum Pembuktian (Erlangga 2012).[52].
} 
hakim seyogyanya dapat menemukan suatu petunjuk berdasarkan penilaian yang bersesuaian dengan keterangan saksi, surat dan keterangan terdakwa menggunakan kecermatan dari hati nuraninya. Penilaian atas kekuatan pembuktian dari suatu petunjuk dalam setiap keadaan tertentu dilakukan oleh hakim dengan arif dan bijaksana setelah ia melakukan pemeriksaan dengan cermat dan teliti. Pada akhirnya persoalan diserahkan pada hakim dalam penerimaannya.

Beberapa ahli berpendapat bahwa alat bukti petunjuk bukan merupakan alat bukti. Seperti pendapat beberapa ahli berikut:

a. Van Bemmelen "akan tetapi kesalahan yang terutama adalah bahwa orang telah menganggap pertunjuk-petunjuk itu sebagai alat bukti, sedang dalam kenyataannya tidak demikian".

b. P. A. F. Lamintang "petunjuk memang hanya merupakan dasar hakim unuk menganggap suatu kenyataan sebagai terbukti, atau dengan perkataan lain petunjuk itu bukan merupakan suatu alat bukti, seperti misalnya keterangan saksi yang secara tegas mengatakan tentang terjadinya suatu kenyataan, melainkan ia hanya merupakan suatu dasar pembuktian mana kemudian hakim dapat mengganggap suatu kenyataan itu sebagai terbukti, misalnya karena adanya kesamaan antara kenyataan tersebut dengan kenyataan yang dipermasalahkan”.

Sifat alat bukti petunjuk adalah bukan merupakan alat bukti langsung (indirect bewijs) dimana keberadaannya hanya berdasarkan alat bukti lainnya. Dalam penggunaannya pun alat bukti petunjuk ada apabila sudah terdapat minimal dua alat bukti yang sah lainnya, dengan demikian kekuatan pembuktiannya pada dasarnya hanya sebagai pelengkap dalam persidangan. ${ }^{37}$

\section{e. Keterangan Terdakwa}

Keterangan terdakwa ialah apa yang terdakwa nyatakan di sidang tentang perbuatan yang ia lakukan atau yang ia ketahui sendiri atau alami sendiri. ${ }^{38}$ Pada persidangan terdakwa akan diminta keterangan guna menemukan petunjuk dari

${ }^{37}$ Hari Sasangka dan Lily Rosita, Hukum Pembuktian Dalam Perkara Pidana (Mandar Maju 2003.[25].

${ }^{38}$ Ps. 189 ayat (1) KUHAP. 
suatu tindak pidana. Pembuktian dalam suatu tindak pidana wajib dilakukan untuk keperluan pemeriksaan sekalipun terdakwa mengakui tindak pidana yang didawakan. Dengan demikian, pengakuan bersalah dari terdakwa tidak menggugurkan kewajiban penuntut umum dan persidangan untuk menambah alat bukti guna menguatkan keterangan terdakwa.

Pasal 189 ayat (4) KUHAP menyebutkan bahwa, keterangan terdakwa saja atau pengakuan terdakwa saja tidak cukup untuk membuktikan bahwa ia bersalah melakukan perbuatan yang didakwakan kepadanya, melainkan harus disertai dengan alat bukti yang lain. Pasal tersebut mempunyai makna bahwa pengakuan terdakwa menurut KUHAP bukan alat bukti yang mempunyai kekuatan pembuktian yang "sempurna" atau bukan volledig bewijs kracht, juga tidak memiliki kekuatan pembuktian yang "menentukan" atau bukam beslissende bewijs kracht. ${ }^{39}$ Keterangan terdakwa tidak cukup untuk dijadikan bukti untuk memperoleh kebenaran materiil, sehingga harus dikuatkan dengan alat bukti lainnya dan keyakinan hakim.

Pada penyidikan tindak pidana Narkotika tes urine dilakukan untuk membutikan ada tidaknya kandungan zat-zat Narkotika di dalam tubuh seorang penyalah guna. Tes urine sebagaimana dimaksud juga merupakan kewenangan penyidik tindak pidana Narkotika yang terdiri dari Polisi, PPNS dan penyidik khusus BNN. Kewenangan penyidik dalam melakukan tes urine diatur dalam Pasal 75 huruf 1 Undang-Undang Nomor 35 Tahun 2009. Tes urine dilakukan sesuai dengan perkembangan ilmu pengetahuan dan teknologi. ${ }^{40}$

Sampel urine yang diperoleh penyidik kemudian dibuatkan berita acara pengambilan. Pada berita acara pengambilan urine tersebut dilampirkan tanggal dan waktu pada saat pengambilan urine. Dalam berita acara tersebut tertera nama penyidik yang mengambil sampel urine dan disebutkan pula di dalamnya nama, tempat dan tanggal lahir, suku/bangsa, agama, pekerjaan serta alamat terhadap seseorang yang dijadikan calon tersangka. Kemudian dijelaskan pula secara detail mulai dari awal hingga akhir proses pengambilan urine tersangka dilakukan. Berita

\footnotetext{
${ }^{39}$ Harahap (n 13). [275].

${ }^{40}$ Penjelasan Ps. 75 huruf 1 UU Narkotika.
} 
acara pengambilan urine ini dibuat dengan sebenar-benarnya atas sumpah jabatan penyidik dan ditanda tangani oleh penyidik dan seseorang tersebut.

Setelah diambil sample urine tersebut disimpan pada wadah plastik dengan diberikan segel atau pada umumnya ditandai dengan tutup merah. Dalam praktiknya sampel yang sudah disegel selanjutnya diperiksa di Unit Pelaksana Teknis Laboratorium Uji Narkoba BNN yang diatur dengan Peraturan Kepala Badan Narkotika Nasional Nomor 5 Tahun 2010 tentang Pedoman Teknis Penyelenggaraan Pelayanan Laboratorium Pengujian Narkoba Pada Badan Narkotika Nasional. Urine merupakan salah satu spesimen biologi yang dapat diuji di laboratorium dan minimal berjumlah 50 mililiter, diatur pada Pasal 1 angka 8 jo. Pasal 5 ayat 2 huruf b Peraturan Kepala Badan Narkotika Nasional Nomor 5 Tahun 2010 tentang Pedoman Teknis Penyelenggaraan Pelayanan Laboratorium Pengujian Narkoba Pada Badan Narkotika Nasional.

Pengujian spesimen biologi yang diduga mengandung narkotika dapat dilakukan untuk keperluan pembuktian perkara (pro justitia), rehabilitasi, ilmu pengetahuan dan teknologi serta pendidikan dan pelatihan diatur pada Pasal 2 ayat (1) Peraturan Kepala Badan Narkotika Nasional Nomor 5 Tahun 2010 tentang Pedoman Teknis Penyelenggaraan Pelayanan Laboratorium Pengujian Narkoba Pada Badan Narkotika Nasional.

Pada Pasal 6 ayat (2) huruf a Perkap BNN Nomor 5 Tahun 2010 berbunyi "Berita acara pengujian: untuk keperluan pembuktian perkara (pro justitia)." Bertolak dari Pasal tersebut, disimpulkan bahwa hasil pengujian laboratorium untuk keperluan pembuktian perkara dituangkan dalam bentuk berita acara pengujian. Berita acara pengujian yang dimaksud merupakan surat yang dibuat menurut ketentuan peraturan perundang-undangan. Sehingga hasil pengujian urine yang diterbitkan oleh laboratorium berupa berita acara merupakan surat yang sah.

Dengan demikian hasil pengujian urine yang diterbitkan oleh laboratorium termasuk dalam alat bukti surat sebagaimana disebutkan dalam Pasal 184 ayat (1) huruf c. Jika diklasifikasikan alat bukti surat sebagaimana ditentukan Pasal 187, maka hasil pengujian tes urine tersebut masuk dalam jenis surat yang disebutkan 
pada huruf $b$. Hasil pengujian urine berupa berita acara merupakan surat yang dibuat menurut ketentuan peraturan perundang-undangan atau surat yang dibuat oleh pejabat mengenai hal yang termasuk dalam tata laksana yang menjadi tanggung jawabnya dan yang diperuntukan bagi pembuktian suatu keadaan.

\section{Kesimpulan}

Kedudukan hasil tes urine dalam pembuktian tindak pidana Narkotika sangat penting khususnya bagi tersangka penyalahgunaan narkotika. Tes urine dilakukan guna membuktikan adanya kandungan zat Narkotika di dalam tubuh seseorang yang kemudian hasilnya dituangkan dalam berita acara. Pada tahap penyidikan seseorang dapat ditetapkan sebagai tersangka penyalahgunaan narkotika berdasarkan hasil positif tes urine dengan disertai alat bukti lainnya.

Pada ketentuan Pasal 184 ayat (1) KUHAP telah disebutkan 5 (lima) jenis alat bukti yang sah yaitu keterangan saksi, keterangan ahli, surat, petunjuk dan keterangan terdakwa. Pada tahap penyidikan hasil tes urine dari laboratorium yang menjadi berita acara diklasifikasikan sebagai alat bukti surat. Berita acara hasil pengujian tes urine yang diklasifikasikan menjadi surat tersebut merupakan alat bukti surat sebagaimana dimaksud pada Pasal 187 huruf $b$.

\section{Daftar Bacaan}

\section{Buku}

Effendi Tolib, Dasar-dasar Hukum Acara Pidana (Perkembangan dan Pembaharuan di Indonesia) (Setara Press 2014).

Hamzah Andi, Perkembangan Hukum Pidana Khusus (Rineka Cipta 1991).

Hamzah M. Chandra, Penjelasan tentang Bukti Permulaan Yang Cukup (PSHK 2014). , Terminologi Hukum Pidana (Sinar Grafika 2008).

Harahap Yahya, Pembahasan Permasalahan dan Penerapan KUHAP (Sinar Grafika 2000). 
Hiariej O.S Eddy, Teori dan Hukum Pembuktian (Erlangga 2012).

Kepolisian Negara Republik Indonesia, Himpunan Bujuklak, Bujuklap dan Bujukmin Proses Penyidikan Tindak Pidana (Polri 2000).

Lamintang P.A.F, KUHAP dengan Pembahasan Secara Yuridis Menurut Yurisprudensi dan Ilmu Pengetahuan Hukum Pidana (Sinar Baru 1984).

Purwoleksono Didik E, Hukum Pidana (AUP 2014). , Hukum Acara Pidana (AUP 2015).

Rifai Ahmad, Penemuan Hukum oleh Hakim Dalam Perspektif Hukum Progresif (Sinar Grafika 2010).

Sasangka Hari dan Lily R, Hukum Pembuktian Dalam Perkara Pidana (Mandar Maju 2003).

Simorangkir J.C.T, Kamus Hukum (Sinar Grafika 2008).

Soesilo R, Taktik dan Teknik Penyidikan Perkara Kriminal (Politea 1980).

Sofyan A, Hukum Acara Pidana Suatu Pengantar (Rangkang Education 2013).

Waluyo Bambang, Sistem Pembuktian dalam Peradilan Indonesia (Sinar Grafika 1996).

, Kamus Hukum (Ghalia Indonesia 1986).

\section{Laman}

Dianti Flora, “Apa Perbedaan Alat Bukti dengan Barang Bukti?”, https://www. hukumonline.com/klinik/detail/ulasan/lt4e8ec99e4d2ae/apa-perbedaan-alatbukti-dengan-barang-bukti-/ (Hukum Online 2011).

Hutomo Dimas, "Strict Liability Dalam Pidana Narkotika", https://www. hukumonline.com/klinik/detail/lt5a54974660b45/strict-liability-dalampidana-narkotika/ (Klinik Hukum Online 2018).

Pramesti Tri Jata Ayu, "arti" bukti permulaan yang cukup" dalam hukum acara pidana", https://www.hukumonline.com/klinik/detail/ulasan/ 1t5940eb061 eb61/arti-bukti-permulaan-yang-cukup-dalam-hukum-acarapidana/ (Hukum Online 2017).

Budi Fauzi P, “Berapa Lama Biasanya Narkotika Bertahan dalam Darah dan 
Urin?", https://hellosehat.com/hidup-sehat/fakta-unik/narkoba-dalam-urindarah/ (Hello Sehat 2017).

Setiawan Ebta, “arti atau makna pembuktian”, https://kbbi.web.id/bukti (KBBI 2019).

Tampubolon Boris, Penjelasan "Bukti yang Cukup” Di Dalam KUHAP, https:// konsultanhukum.web.id/ini-penjelasan-bukti-yang-cukup-di-dalam-kuhap/ (Konsultan Hukum 2011).

Hannanu F Febrice, "Berapa lama kandungan narkoba hilang dalam urine dan darah?”, https://www.alodokter.com/komunitas/topic/berapa-lama-hilangzat-kandungan-narkoba-dalam-urien-dan-darah (Alo Dokter 2019).

\section{Perundang-undangan}

Undang-Undang Dasar Negara Republik Indonesia 1945.

Undang-Undang Nomor 8 Tahun 1981Tentang Hukum Acara Pidana (Lembaran Negara Republik Indonesia Tahun 1981 Nomor 76, Tambahan Lembaran Negara Republik Indonesia Nomor 3209).

Undang-Undang Nomor 5 Tahun 1997 Tentang Psikotropika (Lembaran Negara Republik Indonesia Nomor 3671).

Undang-Undang Nomor 35 Tahun 2009 Tentang Narkotika (Lembaran Negara Republik Indonesia Tahun 2009 Nomor 5062, selanjutnya disebut sebagai UU Narkotika).

Peraturan Pemerintah Tentang Pelaksanaan Undang-Undang Nomor 35 tahun 2009.

Keputusan Bersama Mahkamah Agung, Menteri Kehakiman, Kejaksaan Agung, dan Kapolri No. 08/KMA/1984, No. M.02-KP.10.06 Tahun 1984, No. KEP076/J.A/3/1984, No. Pol KEP/04/III/1984 tentang Peningkatan Koordinasi dalam Penanganan Perkara Pidana (Mahkejapol).

Peraturan Kepala Kepolisian Negara Republik Indonesia No. Pol.Skep/1205/ IX/2000 tentang Pedoman Administrasi Penyidikan Tindak Pidana.

Peraturan Kepala Badan Narkotika Nasional Republik Indonesia Nomor 5 Tahun 2010 tentang Pedoman Teknis Penyelenggaraan Pelayanan Laboratorium Pengujian Narkoba Pada Badan Narkotika Nasional.

Peraturan Kepala Kepolisian Negara Republik Indonesia Nomor 14 Tahun 2012 tentang Manajemen Penyidikan Tindak Pidana. 
1982 Rachmad Firmansyah: Kekuatan Hukum Hasil...

--halaman ini sengaja dibiarkan kosong-- 